\title{
COMPETÊNCIAS GERENCIAIS: UM ESTUDO EM PEQUENAS EMPRESAS DE CONFECÇÕES
}

\author{
Anderson Soncini Pelissari \\ asoncinipelissari@gmail.com \\ Universidade Federal do Espírito Santo - ES / Brasil \\ Inayara Valéria Defreitas Pedroso Gonzalez \\ gonzalezinayara@gmail.com \\ Pontifícia Universidade Católica do Paraná - ES / Brasil \\ Rosângela Maria Vanalle \\ rvanalle@terra.com.br \\ Universidade Nove de Julho - SP / Brasil
}

Recebido em 06/01/2010

Aprovado em 06/04/2010

Disponibilizado em 01/04/2011

Avaliado pelo sistema double blind review

Revista Eletrônica de Administração

Editor: Luís Felipe Nascimento

ISSN 1413-2311 (versão on-line)

Editada pela Escola de Administração da Universidade Federal do Rio Grande do Sul.

Periodicidade: Quadrimestral

Sistema requerido: Adobe Acrobat Reader.

\section{Introdução}

A importância e a força das pequenas empresas no Brasil são indiscutíveis. Sua representatividade pode ser expressa em números. Em conjunto as micro e pequenas empresas respondem por $99,2 \%$ do número total de empresas formais, por $57,2 \%$ dos empregos totais e por $26,0 \%$ da massa salarial e contribuem em torno de $30 \%$ do Produto Interno Bruto (SEBRAE, 2005).

Diante de tal realidade, há que se considerar que a partir da década de 90 , as transformações do cenário globalizado colocaram as pequenas empresas brasileiras sob pressão de novas forças competitivas, em que a adequação contínua às mudanças se apresenta como condição essencial para a manutenção da capacidade de sobrevivência e desenvolvimento, buscando novas formas de superar concorrentes e ampliar a clientela. 
As pequenas empresas estão atualmente numa luta para sobrevirem e se manterem competitivas frente às mudanças sociais, políticas e econômicas que caracterizam a globalização cada vez mais acentuada (PELISSARI, 2007).

Não é preciso fazer uma prolongada discussão sobre as aceleradas mudanças do atual mundo empresarial, caracterizado por uma dinâmica hiper-ativa, por incerteza e caos. As organizações, independente da sua dimensão, têm de enfrentar um desafio constante, intensificação das competições, aumento do poder do cliente e redução do ciclo dos produtos. A organização que confia simplesmente na tradicional competência em custos e na estratégia da diferenciação, encontrará dificuldades crescentes para sustentar a vantagem competitiva. E quando o âmbito é das pequenas empresas o problema é ainda maior (PELISSARI, 2007).

Diante de tais relatos, é necessário o entendimento de que a competência está associada a verbos como saber agir, saber se engajar, mobilizar recursos, assumir responsabilidades, integrar saberes múltiplos e complexos, saber aprender e ter visão estratégica (LE BOTERF, 2003).

Durand (1998) alicerça o conceito de competência em três dimensões - conhecimentos, habilidades e atitudes. O conhecimento é a série de informações assimiladas e estruturadas pelo indivíduo. A habilidade é a capacidade de aplicar o conhecimento adquirido. A atitude é a predisposição em relação à adoção de uma ação.

Conforme abordado por Bitencourt (2005), desenvolver as competências é um processo educativo, que tem integração da aprendizagem com o conhecimento, vivência e prática, que extrapola os limites da sala de aula ou sala de reuniões, sendo um diferencial que o sujeito carregará por toda a vida.

Dentro desse contexto, há que se considerar o desenvolvimento das competências de forma gerencial. De acordo com Miranda (2006), a competência gerencial é um saber agir responsável e reconhecido, que implica mobilizar, integrar, transferir conhecimentos, recursos, habilidades, que agreguem valor econômico à organização e valor social ao indivíduo.

Gerber (1996), a partir de diversas pesquisas procurou delinear o perfil de um estrategista bem sucedido que desenvolve competências gerenciais necessárias. Conforme este autor, para um bom estrategista, é necessário: ser inovador, criador de novos métodos para penetrar e/ou criar novos mercados; ser criativo, lidar com o desconhecido, imaginar o futuro transformando possibilidades em probabilidades, caos em harmonia. 
Há que se considerar ainda, que a direção de um empreendedor está voltada a uma necessidade pessoal de realização, contudo Mussak (2004, p.98) "explica que o empreendedor atinge seus objetivos quando se faz acompanhar do preparo necessário e suficiente, e também da certeza de que nada se obtém sem trabalho duro, paciência e persistência”.

A partir dessas considerações, este trabalho se propôs a analisar as competências gerenciais consideradas essenciais na visão dos gestores das pequenas empresas de confecções do Município de Vila Velha/ES. Para isso, foi desenvolvida uma pesquisa survey de caráter descritivo e direto, aplicando um questionário estruturado em 48 pequenas empresas de confecção, com perguntas abertas e fechadas, de uma amostra aleatória simples. O trabalho é apresentado em sete partes. Depois da parte introdutória, a parte dois aborda As Pequenas Empresas e a Competitividade; Na parte três, faz-se a abordagem inicial sobre Competências e Competências Gerenciais; A parte quatro apresenta as Competências Gerenciais em Pequenas Empresas; Na parte cinco, são abordados os Aspectos Metodológicos da Investigação. Logo em seguida, foi apresentada a Coleta e Análise dos dados, e por fim as Considerações Finais e Sugestões de Pesquisas Futuras.

\section{As Pequenas Empresas e a competitividade}

A simples existência de uma pequena empresa pressupõe que ela tenha um mercado, um produto a oferecer, e é claro, concorrência. Assim, a sobrevivência das micro e pequenas empresas depende da capacidade de competir no mercado (SEBRAE, 2006). Essa capacidade de competição também surge da chamada experiência daquele que gerencia a empresa. A esse respeito, Barringer et al. (2005) argumentam que empreendedores com alguma experiência no setor saem na frente dos outros sem experiência. Conforme os autores (2005), isto acontece porque conhecimentos adquiridos auxiliam a diminuir riscos, e porque o acesso a rede de relacionamentos gera vantagem.

As mudanças das últimas décadas têm causado impacto de forma significativa nas estruturas das organizações quanto à forma de atuação e conseqüentemente nos seus resultados. Este ambiente passou a exigir das organizações, inovação constante da estrutura, dos produtos, serviços, bem como, maior flexibilidade na forma de administrar a organização como um todo, destacando assim, novos modelos de gestão, tornando as organizações mais dinâmicas e competitivas, aspectos decisivos para a manutenção da sua sobrevivência (SILVA, 1997).

O ambiente global dos negócios, dinâmico e extremamente competitivo, exige das pequenas empresas maior agilidade nas decisões, racionalização de custos, flexibilidade e eficiência 
operacional. Diante disso, a qualificação do empresário, aliada à informação - rápida e precisa - tem papel fundamental na cadeia de valor das empresas, para que as decisões permitam um gerenciamento mais eficaz e eficiente, antecipando-se às situações de mudanças provocadas pelo dinamismo atual do mercado (PELISSARI, 2002).

Uma empresa competitiva não se contenta em sobreviver; mas pretende ser reconhecida no mercado pelo seu desempenho, respeitada por toda a cadeia, desde o fornecedor de matériaprima até o consumidor final; ser vista como exemplo pelos concorrentes, ser apreciada e elogiada pelos seus funcionários, conservando uma imagem positiva em todos os sentidos (PELISSARI, 2007).

A esse respeito, o SEBRAE/SP (1999) relata que o objetivo de uma pequena empresa competitiva, é conquistar o respeito e a preferência do consumidor, ser vista como exemplo de qualidade em seu sentido mais amplo; enfim, quer nada menos do que o primeiro lugar.

Ocorre que, para se conquistar competitividade, Ferraz et al (1999) afirmam que é necessário por parte do gestor, a capacidade de formular e implementar estratégias concorrenciais, que lhe permita ampliar ou conservar, de forma duradoura, uma posição sustentável no mercado.

Coutinho e Ferraz (1994, p.10) definem competitividade como sendo "à produtividade das empresas ligada à capacidade dos governos, ao comportamento da sociedade e aos recursos naturais e construídos, e aferidos por indicadores nacionais e internacionais, permitindo conquistar e assegurar fatias do mercado".

Na visão de Resende (2000, p.23), “competitividade pode ser entendida como a obtenção de maior produtividade que os concorrentes, garantindo à sobrevivência, a perenidade, a lucratividade, a continuidade ao longo do tempo e a satisfação dos clientes internos e externos”. De forma complementar, Coutinho e Ferraz (1994) acreditam que os conceitos de qualidade, produtividade e competitividade caminham juntos e estão interligados, pois a competitividade decorre da produtividade e esta, da qualidade.

Levy e Weitz (2000), por outro lado, trazem dentro deste contexto relacionado à competitividade, a relação entre o foco do produto e as exigências do mercado. Competitividade para os autores representa o resultado do grau de foco que o produto alcançou em relação às exigências do mercado, além da dominância que a marca está obtendo em termos de vantagem competitiva.

Kupfer (1991, p.04) alerta que, sua vez, são demarcados pela dinâmica do processo de concorrência, em particular, pela 
interação entre as condições estruturais que o direcionam e as condutas inovativas que o transformam.

Assim, a competitividade pode ser entendida como sendo a capacidade da empresa de gerenciar, sistematicamente, processos, pessoas e funções levando em conta as competências (conhecimento, habilidades e atitudes) do empreendedor. Ao exercitar essa capacidade chamada competitividade empresarial -, o negócio trabalha pontos fortes e oportunidades de melhoria, potencializando sua inserção na cadeia produtiva (SEBRAE, 2006). Ou seja, a competitividade começa pela empresa, mas não se resume a ela. Portanto, "a ação do administrador não se limita a seu próprio negócio, mas abrange o conjunto, ou toda a cadeia produtiva" (SEBRAE, 2007, p. 6).

Para Hitt, Ireland e Hoskisson (2002), atualmente, a natureza fundamental da competição em muitas das indústrias do mundo está em fase de mudança. O ritmo da referida mudança, além de implacável, está aumentando de velocidade. Até mesmo a determinação dos limites de um setor está se tornando um desafio.

Considerando que as organizações existem dentro de muitos ambientes que influenciam seu funcionamento, a administração muitas vezes precisa responder a estas forças ambientais.

Se no mundo globalizado, de concorrência acirrada, competitividade é fundamental para a grande empresa, o que dizer para as micro e pequenas empresas? Por seu próprio porte, elas já enfrentam naturalmente, entre outros entraves, escala limitada, insuficiência tecnológica, falta de acesso a serviços financeiros (SEBRAE, 2006).

Neste sentido, Porter (1998) afirma que existem forças que influenciam na competitividade destas empresas: concorrente, fornecedores, produtos substitutos, novos entrantes e consumidores. Com a globalização, todos esses fatores tiveram suas dimensões ampliadas. A abertura de mercado fez com que essas forças passassem a ser vistas em termos mundiais e não mais regionais (HITT; IRELAND; HOSKISSON, 2002; GRIFFIN, 1998)

Contudo, mesmo existindo a dependência do ambiente externo por parte das pequenas empresas, é possível aprender a tirar vantagens das situações utilizando o conhecimento, como demonstra Griffin (1998, p. 83):

\footnotetext{
Para empresas menores, com orçamento limitado, tentar fazer as pessoas mudarem de idéia com relação àquilo que elas querem está fora de cogitação [...]. A maioria das empresas não pode simplesmente se permitir publicidade suficiente para modificar as atitudes dos clientes. É muito mais prático e lucrativo descobrir quais são essas atitudes e em seguida organizar sua empresa de acordo com elas.
}

Terence (2002) divide os fatores que influenciam a competitividade da pequena empresa em internos e externos: os fatores internos que influenciam positivamente a competitividade são REAd - Edição 68, Volume 17, No 1, jan/abr 2011 - p. 149-180 
relacionados à incorporação e desenvolvimento de novas tecnologias, tamanho, localização e flexibilidade. Por outro lado, os fatores internos que influenciam negativamente a competitividade são de modo geral os ligados a gestão, estrutura, tecnologia e decisão. Os fatores externos que influenciam a competitividade das pequenas empresas são, de forma geral, aspectos que não estão sob gestão do pequeno empresário, pois se encontram no ambiente externo da empresa, como por exemplo, as condições do mercado, o comportamento dos clientes e dos fornecedores.

Kanter (1995) afirma que a força competitiva de uma empresa está em sua capacidade para entender o mercado e na habilidade para comandar ativos intangíveis como: conceitos (idéias principais, visão de objetivos, estratégias de futuro, interação do conjunto, por exemplo), capacidades (recursos e habilidades para transformar idéias em produtos e serviços que criam valores aos clientes), e conexões locais, regionais e até mundiais (alianças estratégicas para aprender e conquistar mercados). Por menor que seja a empresa, é preciso construir um conceito interno de como desenvolver seu negócio em relação ao seu entorno e estabelecer um processo para chegar aos seus resultados.

Neste sentido, Prahalad (2001) alerta para a necessidade de cada vez mais reconhecer a capacidade das descontinuidades iminentes e de aprender a ser inovador, verdadeiros desafios das empresas neste novo milênio: superar as descontinuidades e ousar remodelar as empresas para fazer face aos desafios da nova economia. Assim, o autor defende que é preciso adquirir competências gerenciais para um melhor gerenciamento das empresas.

\section{Abordagem inicial sobre Competências}

Tendo em vista as mudanças no cenário competitivo e a necessidade constante de capacitação do quadro gerencial para acompanhar e gerar essas mudanças, a questão das competências vem despertando o interesse tanto da área acadêmica como gerencial. Neste contexto, o desenvolvimento de competências possui um papel significativo na medida em que contribui para a formulação das pessoas, e para a mudança de atitude em relação às práticas de trabalho, ou mesmo para a percepção da realidade, buscando agregar valor à organização (PIMENTA; BRASIL, 2006).

Schoemaker e Jonker (2005) lecionam que nas organizações do cenário atual, o desenvolvimento e o uso das competências por parte dos indivíduos são cruciais para remanescer no negócio e ser bem sucedido. Além disso, que a organização e o indivíduo tornaram-se mutuamente interdependentes e que, a fim de se movimentar, a organização 
tornou-se dependente das competências dos colaboradores. Ao mesmo tempo o indivíduo necessita da organização - uma comunidade do trabalho - a fim de desenvolver e usar suas competências; conseqüentemente, o relacionamento entre um indivíduo e a organização, é baseado na sintonia.

Assim, a noção de competência aparece como uma forma renovada de pensar o papel e a performance do trabalho nas organizações; não sendo um estado de formação educacional ou profissional, tampouco um conjunto de conhecimentos adquiridos. Nesta perspectiva, a competência não se reduz ao saber, tampouco ao saber-fazer, mas sim à sua capacidade de mobilizar e aplicar esses conhecimentos e capacidades numa condição particular, em que se coloca recursos e restrições próprias à situação específica (RUAS, 2000). Alguém pode conhecer métodos modernos de resolução de problemas e até mesmo ter desenvolvido habilidades relacionadas à sua aplicação, mas pode não perceber o momento e o local adequados para aplicá-los na sua atividade (HIROTA; FORMOSO, 2003).

Quanto ao momento adequado, Coopers e Lybrand (1997) afirmam que todo processo de mudança só ocorre quando se muda a forma de pensar e agir dos membros da organização.

Pode-se destacar ainda, um conceito muito conhecido de competência elaborado por Boyatzis (1982), ou seja, uma característica sobressalente de uma pessoa, que está casualmente relacionada com um desempenho bom ou excelente em um posto de trabalho concreto, em uma organização concreta. Para Parry (1996), competência remete ao relacionamento entre conhecimentos, habilidades e atitudes que afetam a maior parte de uma tarefa (papel ou responsabilidade), e está correlacionada diretamente ao desempenho que possa ser medido contra parâmetros bem-aceitos, sendo que ela pode ser melhorada através de treinamento e desenvolvimento. Fandt (1994) aborda que as competências estão ligadas ao trato social, e que englobam "aprendizado" e "solução de problemas".

De acordo com Le Boterf (1994), a competência não é apenas um somatório de saberes, nem somente saber selecionar, dentro de um repertório de recursos, como conhecimentos, habilidades, qualidades, experiência, emoções entre outros, os elementos pertinentes para a solução de problemas: é preciso saber organizá-los, pois muitos indivíduos, mesmo possuindo os recursos corretos, não sabem combiná-los para a ação, nos momentos em que isso é necessário.

Para Bitencourt (2003, p. 149) "o desenvolvimento de competência gerencial é relacionado ao desenvolvimento de conhecimentos e habilidades. É basicamente ligado à questão da compreensão do negócio e orientação para o consumidor". Por conseguinte, define-se 
competências gerenciais como um saber agir responsável e reconhecido, que implica mobilizar, integrar, transferir conhecimentos, recursos, habilidades, que agreguem valor econômico à organização e valor social ao indivíduo (MIRANDA, 2006).

\subsection{Competências Gerenciais}

No contexto gerencial, o conceito de competência começou a ser construído com Richard Boyatizis. Segundo Wood e Payne apud Ropé e Tanguy (2001, p. 123), "Boyatizis foi a primeira pessoa a usar o termo competência. Seu livro, The Competent Manager: a Model for Effective Performance iniciou o debate acerca do tema competências". O modelo de Boyatizis baseia-se na explicitação de 21 atributos que norteiam a construção de um perfil ideal de gestor.

Boyatizis centralizava o seu trabalho em "Comportamentos Observáveis", baseados numa concepção behaviorista. Seu modelo prevê, ainda, aspectos psicológicos relacionados a três fatores: motivação, auto-imagem e papel social e habilidades.

Na observação de Zarifian (1999) a competência implica uma atitude social e pessoal do profissional em assumir uma responsabilidade frente ao trabalho, estabelecendo um distanciamento crítico em relação às suas ações, lembrando que a noção de que as situações de trabalho são revestidas de singularidade e imprevisibilidade, exigindo uma capacidade do profissional de mobilizar conhecimentos específicos preexistentes para aquela atividade.

Para Melo, Fonsêca e Paiva Júnior (2007) as competências gerenciais e de comprometimento, apontam a necessidade do empreendedor acoplar, no seu bojo de conhecimento, saberes e práticas que permitam que ele gere e desenvolva seu negócio, no ímpeto de mantê-lo "vivo".

A competência gerencial pode ser entendida como a faculdade de mobilizar diversos recursos cognitivos - que inclui saberes, informações, habilidades e as inteligências - para, com eficácia e pertinência, enfrentar e solucionar uma série de situações ou de problemas relacionados com a gestão de uma empresa (RESENDE, 2000).

Neste sentido, destaca-se que a competência gerencial, assim como a individual, é constituída por cinco elementos, conforme Sveiby (1998):

- Conhecimento Explícito, que envolve o conhecimento dos fatos e é adquirido principalmente pela informação, quase sempre pela educação formal.

- Habilidade; arte de "saber fazer" que envolve uma proficiência prática, física e mental, e é adquirida, sobretudo, por treinamento e prática e inclui o conhecimento de regras de procedimento e habilidades de comunicação.

- Experiência; que é adquirida principalmente pela reflexão sobre erros e sucessos passados.

REAd - Edição 68, Volume 17, No 1, jan/abr 2011 - p. 149-180 
- Julgamentos de valor; que são percepções do que o indivíduo acredita estar certo, agindo como filtros conscientes e inconscientes para o processo de saber de cada indivíduo.

- Rede social; que é formada pelas relações do indivíduo com outros seres humanos dentro de um ambiente e uma cultura transmitidas pela tradição.

Lembrando ainda, que o desenvolvimento de competências gerenciais, busca-se alinhar ao objetivo mais amplo de tornar as organizações melhor preparadas para enfrentar os desafios atuais e futuros, especialmente as de pequeno porte, que são mais suscetíveis às mudanças. Sendo que a competência só efetivamente existirá no momento em que agregar algum valor econômico à organização e ao valor social do indivíduo (RUAS, 2000; RESENDE, 2000; SVEIBY, 1998).

Cada organização pode acrescentar aquelas competências que consideram críticas para o alcance de seus resultados específicos (PELISSARI; GONZALEZ; VANALLE, 2007). Dessa forma, as competências gerenciais buscam expressar o espírito da organização, que ajudam alcançar maiores e melhores resultados. No que se refere à questão do desenvolvimento de competências gerenciais, Swieringa e Wierdsma (1992) contribuem para essa reflexão destacando as três dimensões principais que consideram relevantes:

1. O SABER - refere-se ao conhecimento. Implica questionamentos e esforços voltados a informação que possa agregar valor ao trabalho.

2. O SABER FAZER - refere-se a habilidades. Centraliza-se no desenvolvimento de práticas e consciência da ação tomada. As habilidades são o que se deve saber para obter um bom desempenho.

3. O SABER AGIR - refere-se a atitudes. Busca um comportamento mais condizente com a realidade desejada. Neste momento realiza-se a união entre discurso e ação. Deve-se saber agir para se conseguir empregar adequadamente os conhecimentos e habilidades.

Na realidade, as dimensões saber, saber fazer e saber agir estão interrelacionadas e por vezes se confundem. Trata-se de uma análise múltipla de dimensões que se referem ao indivíduo, ao grupo e à organização, uma vez que estes conceitos podem ser amplamente analisados sob os diferentes prismas citados. Um aspecto fundamental para o desenvolvimento de competências gerenciais refere-se à apropriação do conhecimento (saber) em ações no trabalho (saber agir). Essa lógica funciona para qualquer campo de atuação, especificamente para administração, quando se observa que o administrador necessita desenvolver habilidades gerenciais no exercício de suas funções (GRAMIGNA, 2001; BITTENCOURT; BARBOSA, 2004).

Katz (1986) identificou três tipos básicos de competências gerenciais: técnica, humana e conceitual, e afirma que todo administrador precisa das três.

REAd - Edição 68, Volume 17, No 1, jan/abr 2011 - p. 149-180 
- Competência técnica: é a capacidade de usar os procedimentos, técnicas e conhecimentos de um campo de especialização.

- Competência Humana: é a capacidade de trabalhar com outras pessoas, de entendê-las e motivá-las como indivíduos ou como membros e grupos.

- Competência Conceitual: é a capacidade de coordenar e integrar todos os interesses e atividades de uma organização. Implica ver a organização como um todo, compreendendo como suas partes dependem uma das outras e prevendo como uma mudança em qualquer das partes afetará o todo.

Para Fleury e Fleury (2001), as competências gerenciais devem agregar valor econômico para a organização e valor social para o indivíduo, conforme mostra a figura 1.

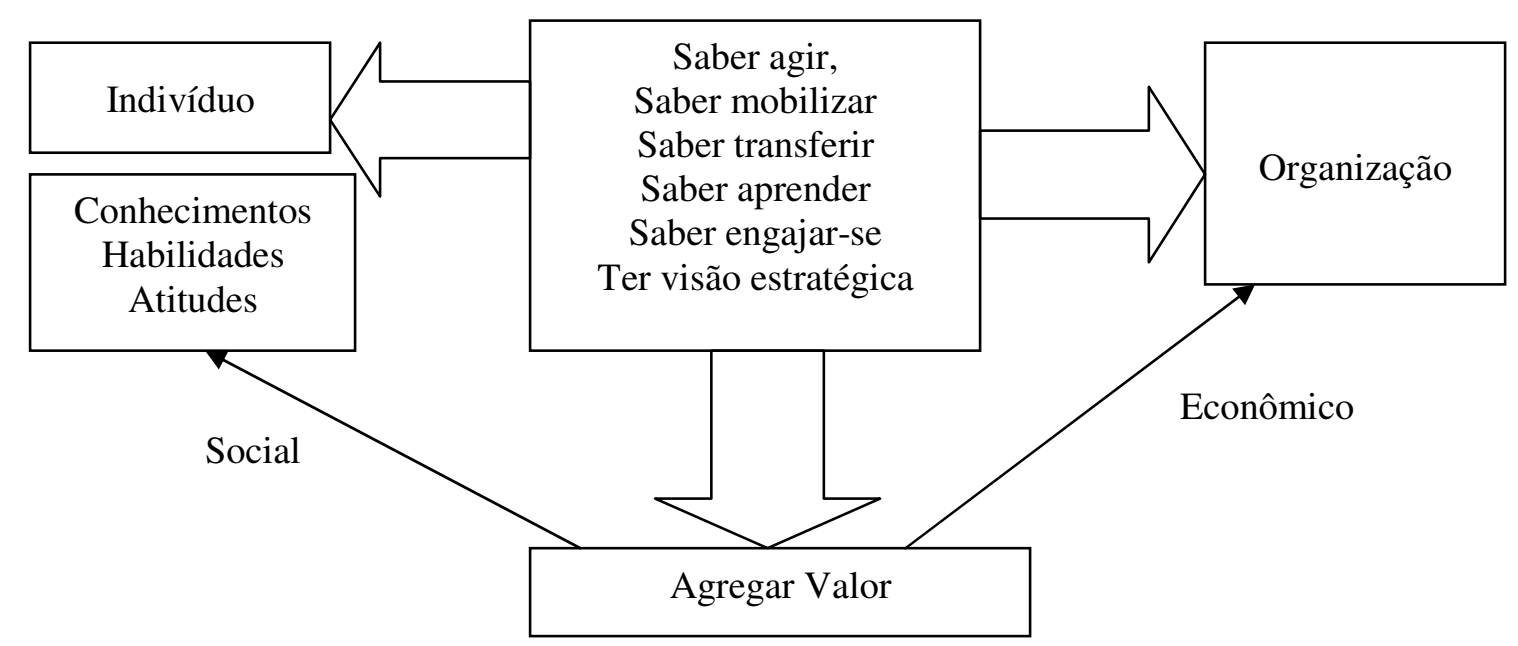

Figura 1 - Competências como fonte de valor para o indivíduo e para a organização.

Fonte: Fleury e Fleury (2001).

Assim, entende-se que as organizações modernas, buscam cada vez mais direcionar os investimentos no desenvolvimento humano, tanto do corpo gerencial como dos demais colaboradores, de modo que possam agregar valor para as pessoas e para a organização, pois a busca desse desenvolvimento colabora para a manutenção e/ou ampliação de seu diferencial competitivo.

As organizações estão percebendo a necessidade de estimular e apoiar o contínuo desenvolvimento das pessoas, como a forma de manter suas vantagens competitivas (DUTRA, 2001). Assim, há a necessidade de se identificar como as competências gerenciais são abordadas nas pequenas empresas.

\section{Competências gerenciais em pequenas empresas}

Culturalmente a pequena empresa tem sua administração alicerçada na figura de seu proprietário-fundador (PELISSARI, 2007). Pelissari (2002) afirma ainda, que o sucesso de uma pequena empresa está estritamente ligado as competências gerenciais de seu 
administrador, bem como a criatividade para estabelecer regras e criar recursos para intensificar a estratégia e a posição competitiva da empresa.

Valle e Macke (2005) desenvolveram um estudo sobre a proposta de uma metodologia para identificação de competências em uma pequena empresa, mas limitaram-se a descrever a vinculação das competências às fases de desenvolvimento da pequena empresa.

Diante dessa abordagem, há que se lembrar que o conceito de competência é pensado como um conjunto de conhecimentos, habilidades e atitudes humanas, que justificam uma alta performance, acreditando-se que as melhores performances estão fundamentadas na inteligência e na personalidade das pessoas. Em outras palavras, a competência é percebida como um estoque de recursos (DUTRA, 2004; FLEURY; FLEURY, 2004).

Em suma o que se busca é um administrador eficaz, capaz de administrar uma empresa levando-a ao lucro e à satisfação dos seus acionistas (PELISSARI, 2007). Há que se considerar ainda, que as pequenas empresas demonstram maior flexibilidade e simplicidade para adaptar-se às transformações do mercado, as mudanças tecnológicas e as novas exigências no que se refere a gestão (SOUZA, 1995; PINHEIRO, 1996).

Robbins (2002) destaca a necessidade de tornar um administrador eficaz, para isso é preciso formar competências gerenciais. Conforme a figura 2, essas competências no âmbito das pequenas empresas são organizadas em dois grupos: conhecimento e habilidades apropriadas. O conhecimento forma a compreensão. As habilidades apropriadas aplicam a compreensão, sendo que, em sua maior parte, a base de conhecimento é derivada das funções gerenciais: planejamento, organização, liderança e controle (ROBBINS, 2002). 
Forças de

mudança

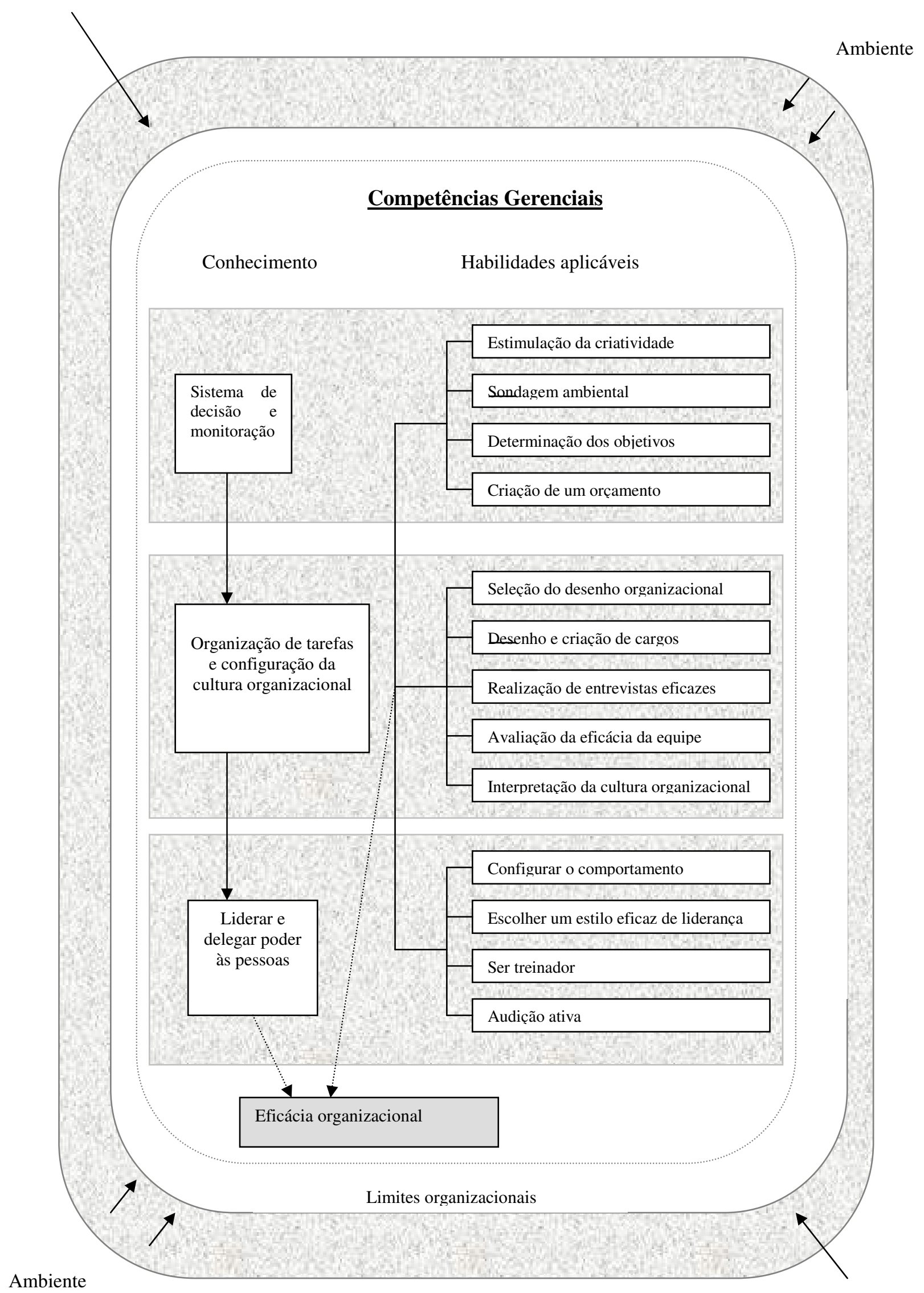

Ambiente

Figura 2 - Competências gerenciais em um mundo em mudanças. Fonte: Robbins (2002, p. 45). 
Apesar de não existir um perfil gerencial específico de administradores de pequenas empresas, algumas competências tendem a se destacar quando grupos de empresários bem sucedidos são estudados (PELISSARI, 2007). Essas competências, segundo Botelho (1998) são:

- Objetividade: capacidade para exercer o poder de decisão, de forma objetiva;

- Inteligência: bom nível intelectual aliado à praticidade e ao bom senso;

- Responsabilidade: disposição para enfrentar desafios, assumindo as conseqüências de suas decisões;

- Estabilidade: capacidade emocional de suportar pressões na atividade profissional;

- Autoridade: não resistência a políticas e decisões razoáveis;

- Visão sistêmica da organização: percepção da organização como um todo, evitando decisões que favoreçam apenas um determinado departamento ou função;

- Capacidade para organizar e solucionar: situações problemáticas exigem soluções, pois existem situações em que é necessário tomar decisões apesar de dispor de pouca ou nenhuma informação;

- Percepção quanto a satisfação de sua equipe de trabalho: a auto-realização é a principal causa da satisfação no trabalho;

- Autoconfiança no desempenho de sua função.

Importa salientar que a formação de administradores no âmbito das pequenas empresas tem provado que aquisição de novas competências cria alternativas para o indivíduo em termos de carreira e de vida. As competências adquiridas pelo administrador facilitam a execução de suas tarefas, que enriquem sua compreensão diante da vida: pessoas com conhecimentos e com habilidades desenvolvidas tornam-se autoconfiantes e contribuem para o sucesso empresarial (PELISSARI; GONZALEZ; VANALLE, 2007).

Depois da sustentação teórica, são abordados os aspectos metodológicos que deram o suporte necessário para a construção da pesquisa. E logo em seguida, apresenta-se a análise dos resultados e as considerações de análise.

\section{Aspectos Metodológicos da Investigação}

Quanto a classificação da pesquisa, este estudo caracteriza-se como descritiva-exploratória. Para Triviños (1995), o foco essencial desta pesquisa está no desejo de conhecer a realidade, uma vez que, têm-se a pretensão de descrever com exatidão os fatos e fenômenos relacionados a esta realidade. Seu objetivo é explorar um problema ou situação para prover critérios e compreensão.

REAd - Edição 68, Volume 17, No 1, jan/abr 2011 - p. 149-180 
No que se refere às bases lógicas da investigação, será empregado o método indutivo. De acordo com Gil (1999), esse método parte da observação de fatos ou fenômenos cujas causas desejam-se conhecer.

O delineamento deste estudo foi realizado através da pesquisa bibliográfica e levantamento (survey). Fachin (1993) destaca que a pesquisa bibliográfica diz respeito ao conjunto de conhecimentos reunidos em livros e que visa conduzir o leitor a determinado assunto, além de conduzir à produção, reprodução, utilização e comunicação das informações coletadas para o desempenho da pesquisa. Através da pesquisa bibliográfica, contextualizou-se a temática e formou-se um esboço teórico-referencial, que serviu de base para a investigação prática.

A pesquisa survey "caracteriza-se pela interrogação direta das pessoas cujo comportamento se deseja conhecer" (GIL, 1999, p. 70). É uma pesquisa formada por um subconjunto da população total através do qual se estimam as características deste universo (RICHARDSON, 1999). Portanto, este tipo de pesquisa apresenta como vantagens a economia de tempo, rapidez na coleta de dados e facilidade de quantificação na busca de conhecimento da realidade pesquisada.

Segundo Babbie (1999), a pesquisa de survey se refere a um tipo particular de pesquisa social empírica. Para Gil (2002, p. 50), "survey se caracteriza pela interrogação direta das pessoas cujo comportamento se deseja conhecer". Na pesquisa survey obtém-se dados ou informações sobre características, ações ou opiniões de determinado grupo de pessoas, população alvo, e o instrumento de pesquisa normalmente utilizado é o questionário (TANUR apud PINSONNEAULT; KRAEMER, 1993). Assim, verifica-se a importância dos critérios adotados para escolha dos sujeitos da pesquisa, ligados ao foco de investigação da pesquisa.

\subsection{Amostra de pesquisa}

Conforme Richardson (1999, p.103), universo "é o conjunto de elementos que possuem determinadas características semelhantes". A amostra compreende um subconjunto de observações da população, ou seja, toma-se parte da população para a realização da pesquisa, e através dela é possível fazer inferências da população (RICHARDSON, 1999).

Para esta pesquisa foram selecionadas as pequenas empresas do segmento industrial de confecções, do município de Vila Velha/ES, população do estudo. Essas empresas não serão aqui identificadas (anonimato solicitado pelas mesmas). Vale destacar que a indústria de confecções do Espírito Santo é destaque na economia regional. O setor é formado, REAd - Edição 68, Volume 17, No 1, jan/abr 2011 - p. 149-180 
principalmente, por micro e pequenas empresas, $98 \%$ ao todo. A maioria delas concentra-se no município de Vila Velha, que abriga aproximadamente $42 \%$ das indústrias, empregando mais de 12.000 funcionários (SEBRAE/ES, 2008).

Para efeito de obtenção de dados, optou-se pela amostra não-probalística intencional, formada pelas 48 empresas cujos administradores participaram do curso Empretec, Sebrae - ES, no ano de 2006. Cabe esclarecer que, este curso é desenvolvido pelo Sebrae/ES com o objetivo de capacitar empresários e potenciais empreendedores no entendimento, auto-avaliação e desenvolvimento de suas características empreendedoras; bem como aspectos de gestão, ambiente e estratégia empresarial.

Assim, a pesquisa foi realizada com os 48 administradores das pequenas empresas de confecções de Vila Velha, ES, que participaram do referido curso, pois, considerou-se que, pelos fundamentos teóricos adquiridos no Empretec, os mesmos responderiam o questionário com maior propriedade.

\section{Coleta e Análise dos Dados}

A pesquisa de campo foi realizada mediante a aplicação de questionário junto aos empresários das pequenas empresas do ramo de confecções, visando comprovar as questões que foram levantadas com base no foco do referencial, competências gerenciais. Conforme Richardson (1999, p.142), geralmente os questionários “cumprem pelo menos duas funções: descrever as características e medir determinadas variáveis de um grupo social. A informação obtida por meio de questionário permite observar as características de um indivíduo ou grupo".

O questionário do presente estudo combinou perguntas abertas e fechadas. As perguntas abertas permitiram a investigação sobre a percepção dos empresários em relação as competências gerenciais nas organizações estudadas e foram destinadas a aprofundar as opiniões de cada entrevistado. Os sujeitos selecionados, 48 empresários, foram aqueles que representavam as melhores fontes de informação para o objetivo do trabalho proposto (RICHARDSON, 1999; MARCONI; LAKATOS, 2003). Já, as perguntas fechadas destinaram-se a obter informação socio-demográfica do entrevistado e respostas de identificação de opiniões.

Primeiramente, antes de se chegar ao questionário definitivo, foi feito um pré-teste com 03 empresários. Segundo Gil (2000), no pré-teste há de considerar os seguintes aspectos: clareza e precisão dos termos, quantidade de perguntas, forma das perguntas, ordem das perguntas e introdução. O pré-teste permitiu identificar as falhas e assim proceder às reformulações REAd - Edição 68, Volume 17, No 1, jan/abr 2011 - p. 149-180 
necessárias; assim, pode-se afirmar que o questionário é válido e fidedigno. O questionário foi aplicado pelo próprio pesquisador, via e-mail, fax ou presencialmente (in-loco), mediante contato telefônico preliminar com os gestores pesquisados.

No presente capítulo, apresenta-se o conjunto de dados levantados junto aos empresários do ramo de confecções do Pólo da Glória, Vila Velha - ES, num total de 48 entrevistados, conforme comentado. Os dados são apresentados na íntegra, comentados e expressos por gráficos e ou demonstrativos numéricos, quando necessário. Desta forma, a partir deste ponto são apresentados os dados coletados e as análises, e por último, as conclusões da pesquisa.

\section{a) Experiência no ramo}

O empresário precisa ter o conhecimento necessário para gerar seus produtos ou serviços. $\mathrm{Na}$ maioria dos casos de sucesso, ele domina as noções básicas necessárias para desenvolver o negócio. O conhecimento direto é demonstrado pelo empresário ou por seus sócios; o indireto implica no seu acesso através de ramos de negócios já consagrados, como, por exemplo, as franquias. Nesta modalidade, o empresário recebe todo o conhecimento necessário para desenvolver um novo negócio, inclusive treinamento e orientação profissional (DEGEN; MELO, 1989).

Seguindo este pensamento, os autores (1989) enfatizam que a escolha de um ramo de negócio deve ser canalizada para onde já se disponha de alguma experiência, além da respectiva tradição familiar naquele ramo. Isso foi constatado no Pólo de Confecções da Glória, Vila Velha - ES, pois 64,58\% dos entrevistados afirmaram que optaram pelo ramo de confecções pelo fato de já terem alguma experiência no ramo, e os demais, 34,42\%, não têm experiência, conforme pode ser visualizado na figura 3 :

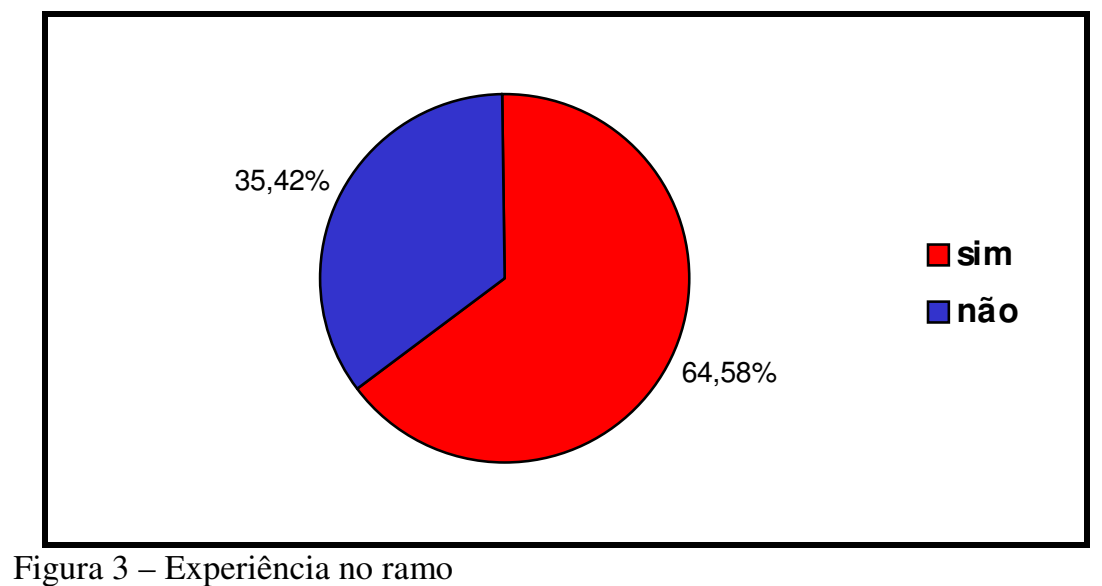

Fonte: Dados Coletados, 2006. 


\section{Considerações de análise}

Os gestores entrevistados que revelaram já ter alguma experiência no ramo, afirmaram ser necessário ocorrer uma combinação de educação com experiência para se assumir um empreendimento, e que é preciso que haja por parte do gestor a capacidade de identificar os tipos de iniciativas necessárias para preparações específicas, sendo algumas qualificações indispensáveis para a condução do negócio. Dentre as qualificações mais importantes todos destacaram as informações e conhecimentos sobre o setor, o que vai ao encontro das análises de Barringer et al. (2005) que afirmam que a experiência traz vantagens e facilidades.

\section{b) Natureza da experiência}

De acordo com a figura 4, dos empresários que admitiram terem tido experiência no ramo antes de abrir sua empresa (31 ao todo), 77,42\% relataram que esta experiência foi como profissional, trabalhando em empresas do ramo ou similares, e 22,58\% como empresário, em empreendimentos anteriores.

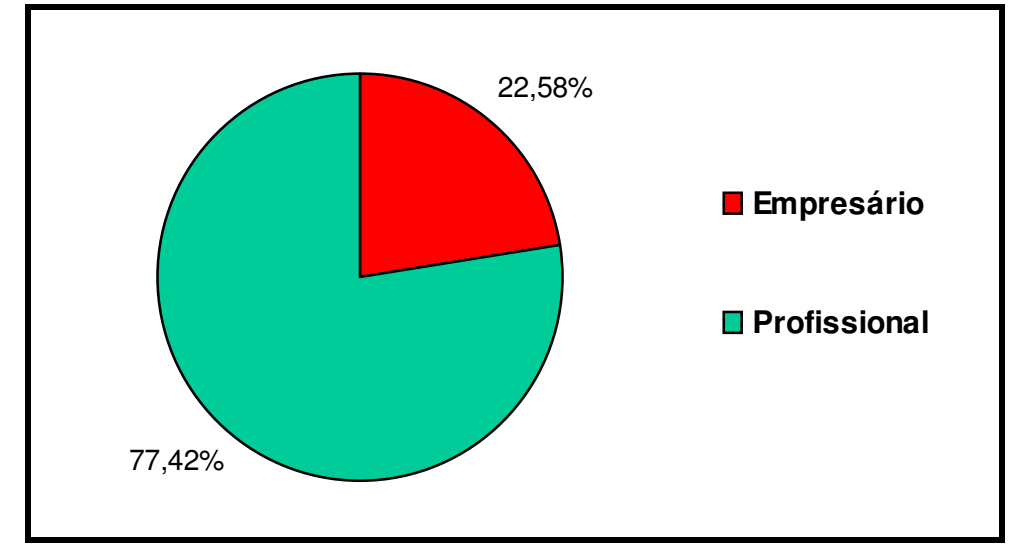

Figura 4 - Natureza da experiência

Fonte: Dados Coletados, 2006.

\section{Considerações de análise}

De acordo com Stoner e Freeman (1999), o ambiente atual criou um número recorde de oportunidades e um número correspondente de empreendedores. Para Pelissari, Gonzalez e Vanalle (2007), a maior parte dos empreendedores ganha experiência trabalhando para outros. Ter a competência especial, que é o desejo de iniciar um negócio, aliado à habilidade ou à experiência para competir com eficácia tão logo a empresa iniciar suas atividades, é diferente de se ter somente o desejo de se iniciar um negócio sem aquelas qualidades. Neste último caso - ausência de habilidade ou experiência torna as chances de sobrevivência e crescimento praticamente nulas.

REAd - Edição 68, Volume 17, Nº 1, jan/abr 2011 - p. 149-180 


\section{c) Competências gerenciais nas empresas pesquisadas}

Diante do atual ambiente globalizado, a informação e o conhecimento tornam-se diferenciais das pequenas empresas que pretendem destacar-se no mercado, efetivar a perenidade, a sobrevivência e a competitividade, conforme foi constatado. As rápidas e profundas mudanças econômicas, sociais e tecnológicas trouxe para as pequenas empresas, novos desafios, que se traduzem em pressões para a reestruturação produtiva. Segundo informaram os entrevistados, para as empresas pesquisadas, a capacitação é tida como um programa que abrange tanto a aquisição de novas habilidades e conhecimentos, quanto o desenvolvimento de outras características comportamentais, sendo que, esta capacitação é realizada mediante treinamentos periódicos, cursos, seminários, palestras, workshopings.

Pensando na sua capacitação gerencial, os administradores das empresas pesquisadas participam (duas vezes ao ano, no mínimo) de congressos, seminários e cursos de atualização e, utilizam a Internet como um instrumento de capacitação, demonstrando assim, que estes têm preocupação com sua formação profissional.

No que se refere à área gerencial, o quadro 1 sintetiza as competências gerenciais fundamentais para agregar valor ao negócio, segundo a opinião dos entrevistados:

\begin{tabular}{|c|c|}
\hline - Competências Técnicas & $\begin{array}{l}\text { - Domínio técnico dos processos. } \\
\text { - Capacidade de identificar e solucionar problemas. } \\
\text { - Orientação para custos e resultados. } \\
\text { - Capacidade de inovar tecnologicamente. }\end{array}$ \\
\hline - Competências Humanas & $\begin{array}{l}\text { - Capacidade de liderar e participar de equipes para } \\
\text { atingimento das metas. } \\
\text { - Prática da competência social, comunicação. } \\
\text { - Capacidade de motivar e envolver a equipe. } \\
\text { - Abertura para adaptar-se às mudanças. }\end{array}$ \\
\hline - Competências Conceituais & $\begin{array}{l}\text { - Visão do negócio em sua totalidade. } \\
\text { - Capacidade de inter-relacionar a realidade externa com } \\
\text { a condução do negócio. } \\
\text { - Capacidade de entender conceitos e transferi-los para a } \\
\text { realidade do negócio. } \\
\text { Capacidade de integrar sua parte para contribuir no } \\
\text { negócio. }\end{array}$ \\
\hline - Competências Gerais & $\begin{array}{l}\text { - Negociação, mobilização para a mudança. } \\
\text { - Sensibilidade cultural e trabalho em times. } \\
\text { - Habilidades gerenciais para manejar os recursos } \\
\text { materiais e humanos disponíveis. } \\
\text { - Atitudes adequadas. }\end{array}$ \\
\hline
\end{tabular}

REAd - Edição 68, Volume 17, No 1, jan/abr 2011 - p. 149-180 


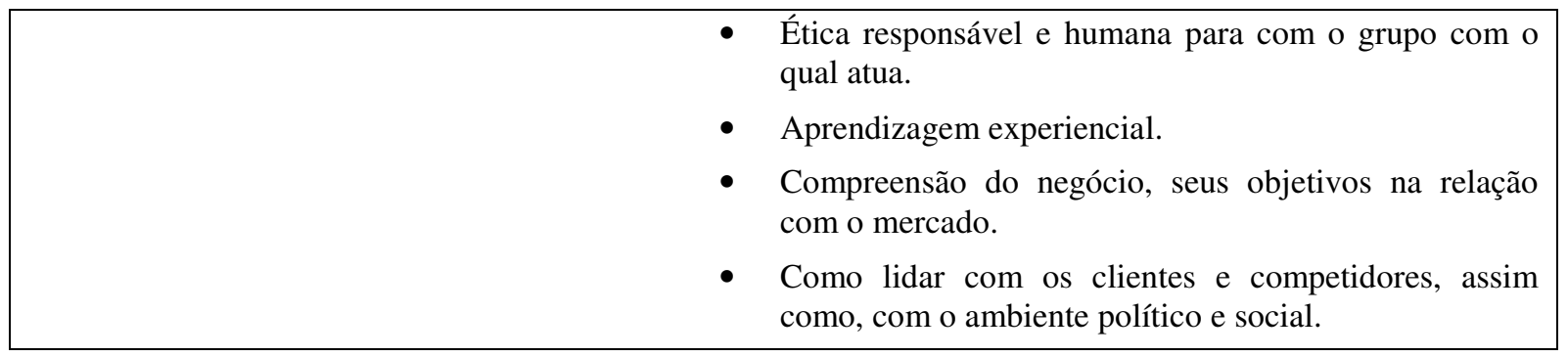

Quadro 1 - Competências gerenciais fundamentais

Fonte: Dados coletados (2006)

Seguindo a visão de Prahalad (2001), constata-se que os gestores que responderam ao questionário, citaram como importante o desenvolvimento de competências gerenciais frente às descontinuidades inerentes as mudanças do ambiente. E, por meio do questionário, foi possível extrair dos gestores como sendo competências gerenciais relevantes na condução das pequenas empresas de confecções, as competências apresentadas no Quadro 1, que, juntamente com a literatura pesquisada puderam ser sintetizadas na forma da figura 5 .

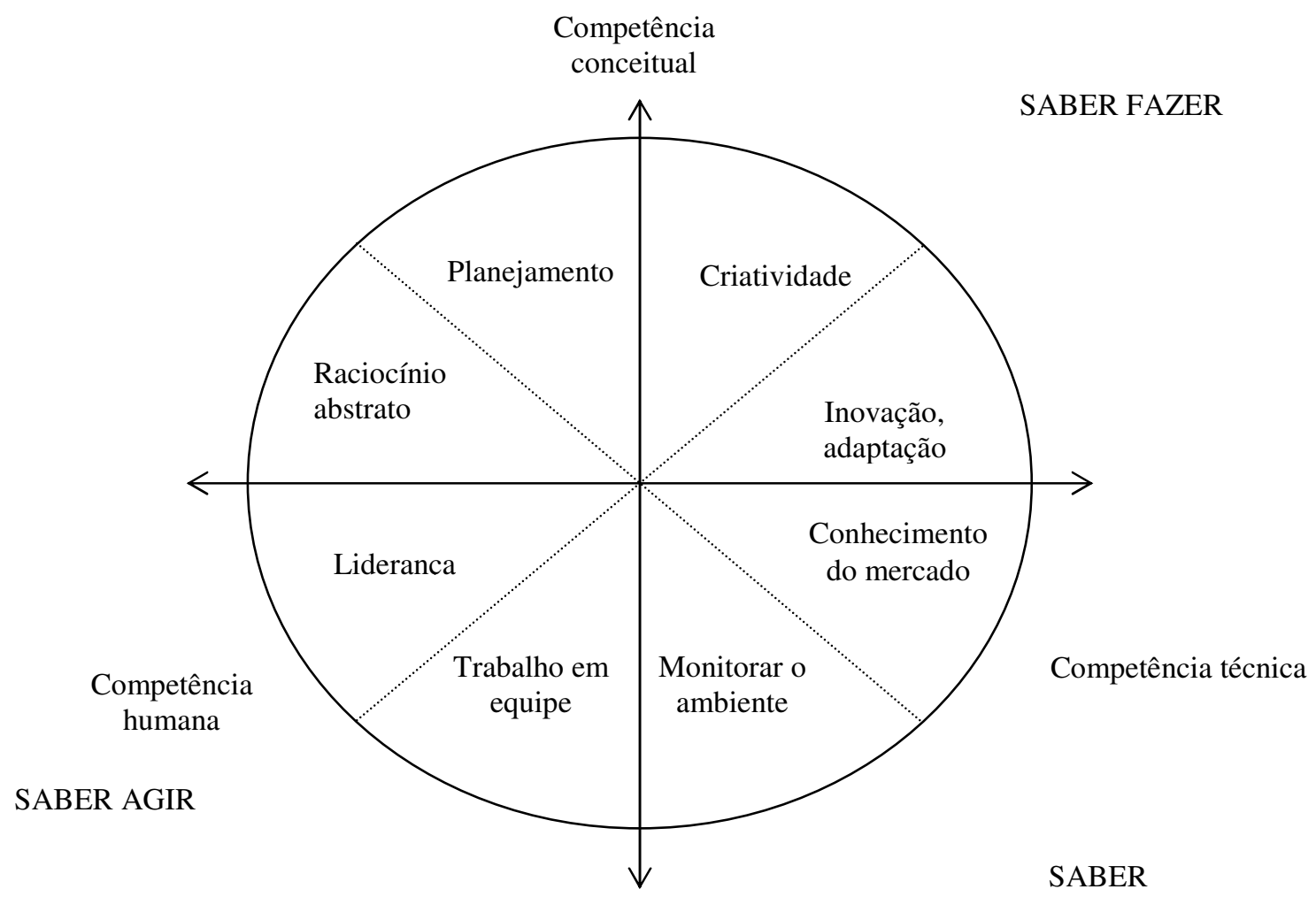

Figura 5 - Competências gerenciais básicas no âmbito das pequenas empresas.

Fonte: Elaboração do autor (2006) 
A figura acima revela tanto a visão de competência que os gestores acreditam ser necessária para atuarem no mercado, quanto a visão dos autores investigados em relação a competências gerenciais. As informações internas do círculo espelham as informações obtidas junto aos gestores, sendo as externas extraídas da revisão da literatura.

\section{d) Fatores considerados importantes para a competência gerencial}

A figura 6 evidencia que no Pólo de Confecções do bairro Glória, 29,16\% dos empresários entrevistados consideram o bom conhecimento do mercado em que atuam - o principal fator determinante do sucesso da empresa. Outros fatores citados foram:

Ter um bom administrador

Boa estratégia de vendas

Criatividade do empresário

Empresário com persistência/perseverança

Ter acesso a novas tecnologias

Reinvestimento dos lucros na própria empresa
14,58\% dos empresários

$16,67 \%$ dos empresários

$12,50 \%$ dos empresários

10,42\% dos empresários

10,42\% dos empresários

6,25\% dos empresários

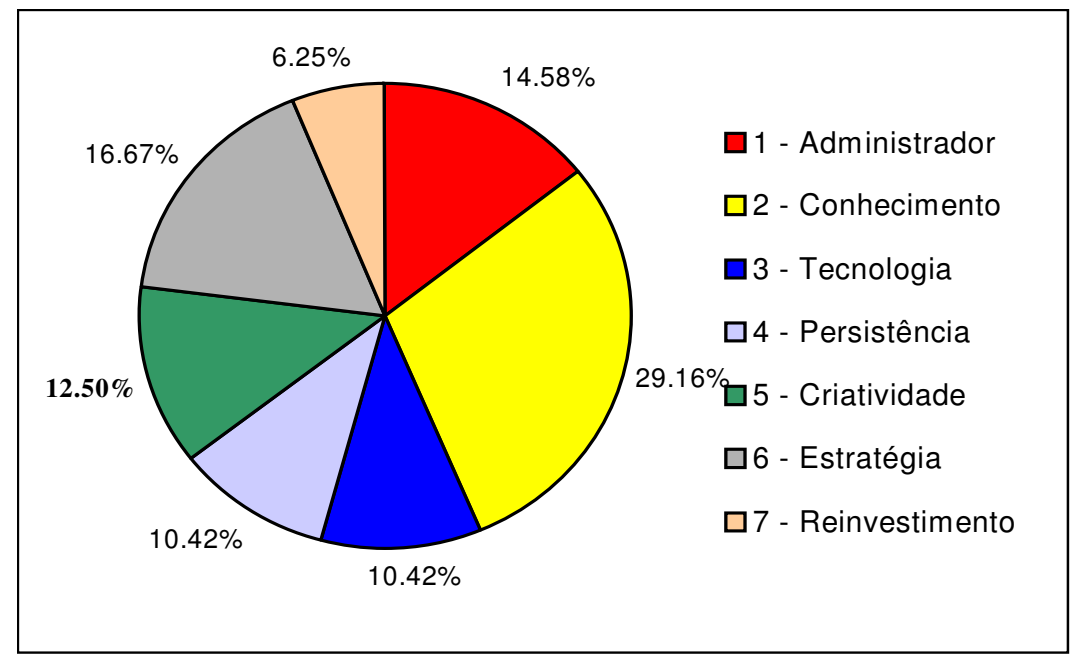

Figura 6 - Fatores considerados importantes para o sucesso da empresa Fonte: Dados Coletados, 2006.

\section{Considerações de análise}

Ruas (2005, p. 124) aborda que, "tanto as organizações, quanto as pessoas, particularmente gestores, precisam rever as capacidades que disponibilizam e empregam nos processos". Aborda (2005, p. 125) ainda que, "a dimensão competências gerenciais, é uma das configurações da gestão empresarial que ganha espaço com a turbulência do atual ambiente de negócios". E, neste sentido, evidenciou-se que um dos entrevistados complementa essa idéia afirmando: "Ainda estou buscando alcançar sucesso, mas creio que só em estar ativa nos 
negócios nos dias de hoje, onde buscamos superar tantas dificuldades, trabalhando com honestidade, dignidade, respeito e muita dedicação, já me sinto uma pessoa vitoriosa”.

\section{e) Decisões estratégicas}

Com relação à análise da figura 7 a seguir, verifica-se que, para a maioria dos empresários, $56,25 \%$, as decisões estratégicas da empresa são tomadas de maneira consciente e sólida, com base no conhecimento da situação e mercado, o que torna as decisões mais acertadas. Enquanto 39,58\% tomam suas decisões com base em experiências próprias ou de terceiros, e 4,17\% fazem uma análise antes de qualquer decisão estratégica.

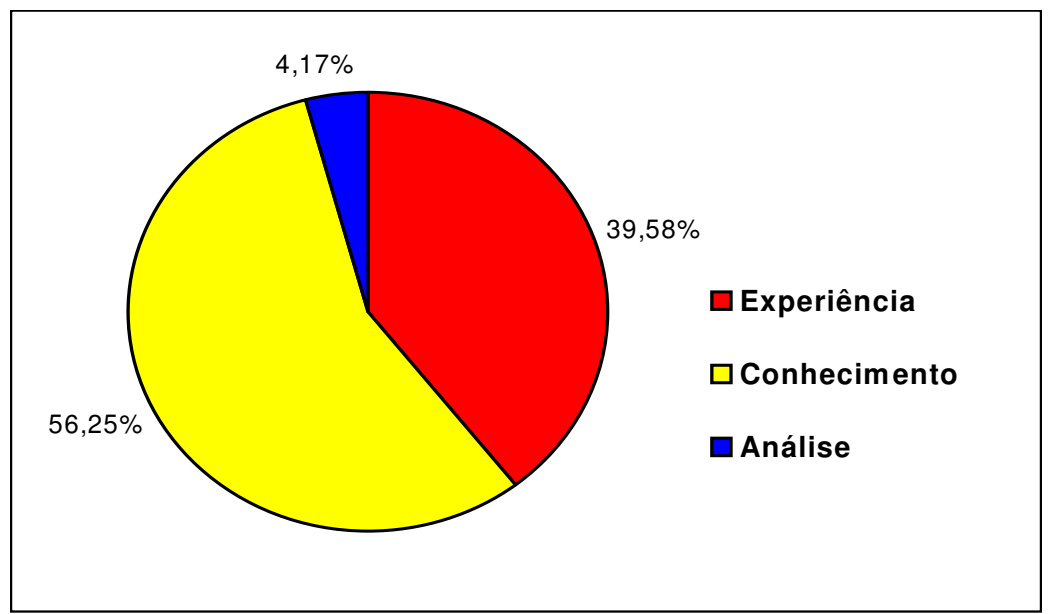

Figura 7 - Decisões estratégicas Fonte: Dados Coletados, 2006.

\section{Considerações de análise}

Somente a vontade de iniciar um negócio próprio não é suficiente para garantir seu sucesso, como sugere a bibliografia consultada. Também se pode afirmar que o simples conhecimento a respeito de algum fato sem a correspondente prática, não ocasionará nenhuma mudança no estado original. Em se tratando do meio empresarial, o conhecimento gerencial pode ser observado com a adoção de determinados procedimentos e a utilização de ferramentas específicas pelos administradores no seu exercício diário.

\section{f) Fatores estratégicos}

O quadro 2 foi construído com base na entrevista realizada com os administradores das empresas pesquisadas; salientando que as categorias aqui levantadas, foram delineadas com base na fundamentação teórica do estudo. O objetivo aqui foi levantar junto aos entrevistados algumas questões relevantes que envolvem a administração das pequenas empresas, com escalas divididas em: muita importância, importância média e pouca importância: 


\begin{tabular}{|ll|}
\hline & a) Saber tratar a complexidade e a diversidade; prospectar para \\
& poder antecipar-se; agir em tempo certo com visão sistêmica. \\
& b) Entender e saber utilizar diferentes fontes de recursos \\
- Muita importância & (financeiros, humanos, informacionais); saber buscar parcerias e \\
& integrá-las ao negócio. \\
& c) Criar a cultura corporativa, os sistemas e os mecanismos \\
& requeridos para a aprendizagem. d) Conhecer e entender \\
& profundamente o negócio da organização e seu ambiente, \\
& identificando vantagens competitivas e oportunidades. \\
\hline & a) Conhecer as linguagens dos negócios e dos mercados; saber \\
ouvir e comunicar-se eficientemente com stakeholders (todas as \\
pessoas ou empresas que, de alguma maneira, são influenciadas \\
pelas ações de uma organização). \\
b) Saber avaliar as conseqüências das decisões, tanto no plano \\
interno da empresa quanto no nível externo da sociedade.
\end{tabular}

Quadro 2 - Fatores estratégicos

Fonte: Dados coletados (2006)

Os entrevistados apontaram total importância nas questões a, b, c, d. Assim, buscam-se evidenciar a justificativa deste grau de relevância. Saber tratar a complexidade e a diversidade; saber prospectar para poder antecipar-se; agir em tempo certo com visão sistêmica é muito importante para o sucesso empresarial porque o mercado, o processo, as leis, o governo, os fornecedores, os clientes, enfim, os Stakeholders, estão em constante mutação ao redor da organização e o administrador precisa estar atento para que a tomada de decisão seja coerente.

Também, é de total relevância entender e saber utilizar diferentes fontes de recursos (financeiros, humanos, informacionais...); saber buscar parcerias e integrá-las ao negócio, pois isoladamente a organização não cresce e nem mesmo se mantém no mercado e, porque o mercado é instável, a empresa precisa definir junto aos parceiros / clientes, financiamento de capital de giro para a fabricação dos produtos. Buscando também, informações necessárias do que fabricar e o quanto fabricar, para ter noção da capacidade produtiva.

Outro ponto central à gestão das pequenas organizações é conhecer e entender profundamente o negócio da organização e seu ambiente, identificando vantagens competitivas e oportunidades, porque a organização deve estar atenta a tudo o que acontece em relação ao seu setor.

\section{g) Áreas de prioridade dentro da empresa}

Todas as áreas são essenciais dentro da empresa. Mas, a área com maior prioridade de conhecimento na visão dos entrevistados é a de planejamento (29 entrevistados), que alicerça 
todas as demais.

- A área de produção fica em segundo lugar na visão de 14 entrevistados.

- Vendas em terceiro (12);

- Área financeira em quarto (13);

- Contabilidade em quinto (15);

- Marketing em sexto (15);

- Recursos humanos em sétimo (12).

\begin{tabular}{|l|c|c|c|c|c|c|c|c|}
\hline & $1^{\mathbf{o}}$ & $2^{\mathbf{o}}$ & $3^{\mathbf{o}}$ & $4^{\mathbf{o}}$ & $5^{\mathbf{o}}$ & $6^{\mathbf{o}}$ & $7^{\mathbf{o}}$ & $8^{\mathbf{o}}$ \\
\hline Planejamento & 29 & 8 & 6 & 2 & 3 & 1 & 3 & 0 \\
\hline Vendas & 5 & 6 & 12 & 10 & 2 & 8 & 4 & 7 \\
\hline Recursos humanos & 4 & 5 & 6 & 5 & 8 & 7 & 12 & 3 \\
\hline Marketing & 0 & 8 & 2 & 3 & 5 & 15 & 9 & 3 \\
\hline Informática & 0 & 0 & 3 & 4 & 3 & 3 & 10 & 22 \\
\hline Financeira & 0 & 6 & 10 & 13 & 3 & 8 & 4 & 4 \\
\hline Contabilidade & 1 & 1 & 0 & 6 & 15 & 6 & 4 & 8 \\
\hline Produção & 9 & 14 & 9 & 5 & 8 & 0 & 2 & 1 \\
\hline
\end{tabular}

Tabela 1 - Áreas de prioridade dentro da empresa*

Fonte: Dados Coletados, 2006.

* Questão permite múltiplas escolhas

\section{Considerações de análise}

Destaca-se que embora, a utilização da Tecnologia da Informação, hoje, seja parte integrante do processo de transformação das organizações, sendo necessário, portanto, investir em inovações tecnológicas, utilizar sistemas de informações gerenciais e implementar o processo de mudança organizacional, 22 empresários não priorizam esta área, relegando a informática ao $8^{\circ}$ lugar em grau de importância.

No entanto é sabido que, para uma empresa ser bem sucedida faz-se necessário existir uma sincronia entre todas as áreas, pois é igual um time onde todos têm que jogar. Assim, é preciso estar atento e reconhecer as mudanças ambientais provocadas pela globalização, pelo acelerado avanço tecnológico e pelo aumento extraordinário do volume de informações que também alteraram prioridades dentre as ações empresariais voltadas para a competitividade.

\section{h) Sucesso}

Conforme figura 8, ao serem questionados quanto ao método adotado para avaliar o sucesso das empresas no mercado, 50,00\% dos entrevistados afirmaram que é através da boa aceitação do produto, $35,42 \%$ pelo lucro obtido no final de cada exercício, 8,33\% comparando a Taxa 
Interna de Retorno com o Custo de Capital e 6,25\% pela necessidade de ampliação do mercado.

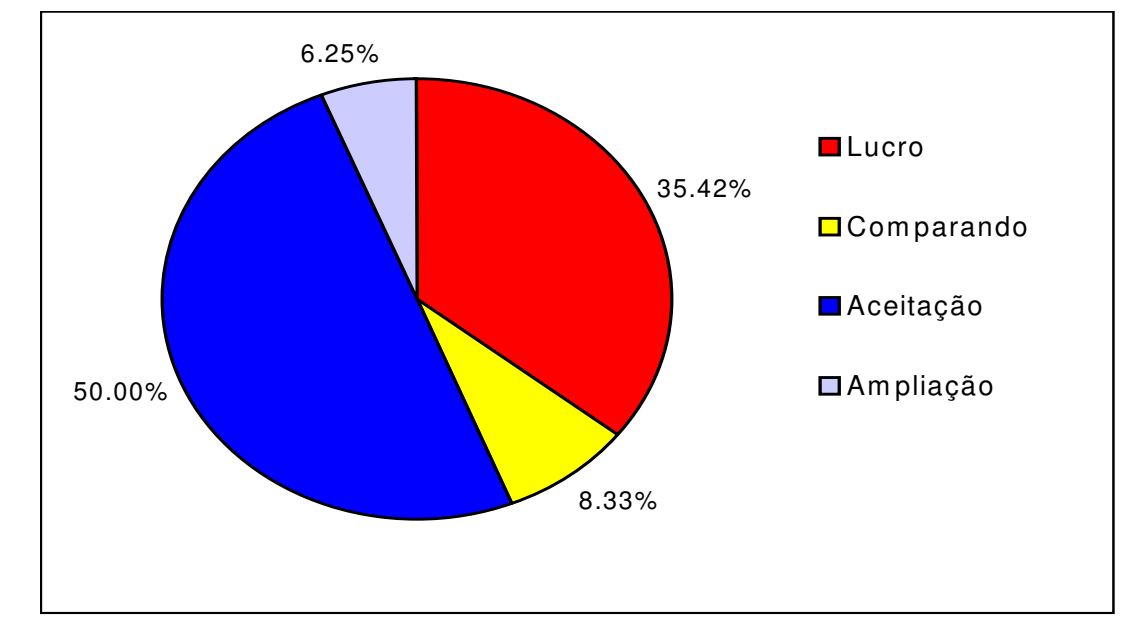

Figura 8 - Fator de medição do sucesso

Fonte: Dados Coletados, 2006.

\section{Considerações de análise}

Estes são fatores importantes, no entanto estão ficando obsoletos e precisam ser "reciclados", pois hoje, em um ambiente de constantes mudanças, a maior vantagem competitiva que uma empresa pode possuir é a visão do futuro, pois sem esta, empresário nenhum conseguirá fazer o sucesso perdurar.

\section{i) Sucesso na gerência}

No final da entrevista, foi solicitado aos empresários, que atribuíssem uma nota de 0 a 10 à sua administração.

Considerando que $79,16 \%$ atribuíram uma nota entre 7 e 8 , constatou-se que os próprios empresários detectaram falhas em sua administração, o que é fundamental estar consciente dos nossos pontos fortes e fracos, e é obrigação de cada um, fortalecer e aprimorar os já desenvolvidos e buscar melhorar, de maneira que os pontos fracos sejam eliminados, com brevidade. Só 10,41\% atribuiu nota 10 à sua administração. Ressalta-se que, nenhum empresário atribuiu nota inferior a 5 à sua administração.

\section{Considerações de análise}

De acordo com Pereira e Santos (1995), a ênfase na realização da vontade própria pode ser considerada um aspecto importante para o sucesso em quase todas as profissões, embora o seu REAd - Edição 68, Volume 17, No 1, jan/abr 2011 - p. 149-180 
excesso, sem o complemento da afetividade nas relações humanas, leva a uma busca pelo poder sem medida.

Considera também empreendedor bem sucedido, aquele que é capaz de administrar suas necessidades e frustrações, sobrepondo-os a abertura de novas oportunidades de realização, mantendo a automotivação, mesmo em situação de fracasso momentâneo. Diante do exposto, comenta-se que as perspectivas de sobrevivência e sucesso aumentam muito, quando se sabe o que especificamente fazer para atingi-la. A presença do conhecimento e controle do empresário sobre toda a operação tem grande responsabilidade sobre o crescimento da empresa.

\section{Considerações finais e sugestões de pesquisas futuras}

A partir da figura 5, que representa o confronto entre àquilo que a literatura denomina estar ligado às competências gerenciais, com aquilo que os sujeitos desta pesquisa afirmaram ser de muita importância para a administração das micro e pequenas empresas, foi possível identificar como é caracterizado o sistema de competências gerenciais para esses gestores do pólo de confecções de Vila Velha.

De acordo com os gestores do pólo de Vila Velha, é preciso saber tratar a complexidade e a diversidade, e prospectar para poder antecipar-se. Assim, quando se compara tal visão com a teoria, verifica-se que ela está ligada ao conhecimento de mercado que faz parte da competência técnica.

Além dessa competência, os mesmos gestores acreditam ser muito importante agir em tempo certo com visão sistêmica, o que quer dizer que é necessário planejamento e conhecimento de mercado, respectivamente, competência conceitual e técnica.

Entender e saber utilizar diferentes fontes de recursos, saber fazer, também está incluída na lista dos pontos mais importantes para esses gestores, ou seja, eles consideram teoricamente, a competência conceitual. Ao mesmo tempo, incluem a liderança (competência humana) na condução do negócio, e o saber buscar parcerias e integrá-las ao negócio, além da criatividade, inovação e adaptação (competência conceitual).

Por fim, foi possível verificar que os gestores valorizam a criação de uma cultura corporativa, de sistemas e mecanismos requeridos para a aprendizagem, o que reúne elementos da competência tanto conceitual como humana, conforme a teoria.

Em resumo, apesar de a competência humana ter sido descrita como importante no processo de condução dos negócios, os gestores entrevistados revelaram dar maior ênfase às 
competências técnica e conceitual, visto que consideraram ser de maior relevância para eles enquanto administradores, o conhecimento do negócio da organização e seu ambiente, e a identificação das vantagens competitivas e oportunidades.

O caminho para o domínio da capacidade plena gerencial é basicamente um processo de aprendizado para toda a vida, e que se dá com o passar do tempo. Embora possa ocorrer, às vezes, sem que se tenha consciência de estar aprendendo, em geral é preciso um esforço concentrado na capacidade de gerenciar eficazmente, compreendendo os novos desafios e estando aberto às mudanças, praticando o teórico com habilidades.

Pela carência de estudos nesse segmento, entre as sugestões para dar continuidade a este trabalho menciona-se: (i) Para futuros estudos, sugere-se a investigação em outros setores ou mesmo no segmento de confecções, no intuito de conferir uma melhor compreensão sobre o desenvolvimento de atualização das competências gerenciais; (ii) pesquisas que contrastem o desenvolvimento de competências gerenciais e sua relação com o desempenho alcançado pelas organizações pesquisadas; e, (iii) como visto no decorrer do presente estudo, os administradores das pequenas empresas em específico, tem várias responsabilidades gerenciais além do desempenho das funções do processo administrativo.

\section{REFERÊNCIAS}

BABBIE, Earl. Métodos de Pesquisa Survey. Tradução de Guilherme Cezarino. Editora UFMG, BH, 1999, 519 p.

BARRINGER, B; JONES F; NEUBAUM, D. A quantitative content analysis of the characteristics of rapidgrowth, firms and their founders; Journal of Business Venturing, $v$. 20, pp. 663-687, 2005.

BITENCOURT, C. A gestão de competências como alternativa de formação e desenvolvimento nas organizações: uma reflexão crítica baseada na percepção de um grupo de gestores. In: RUAS, R; ANTONELLO, C; BOFF, L. H. (Org). Aprendizagem Organizacional e Competências. Porto Alegre: Bookman, 2005.

BITTENCOURT, C.; BARBOSA, A. C. Q. A gestão por competências. In: Bittencourt, C. editor. Gestão contemporânea de pessoas. Porto Alegre (RS): Bookman; 2004.

BITENCOURT, C. C. Competências Gerenciais e a contribuição da aprendizagem organizacional - a experiência de três empresas australianas. Revista de Administração Mackenzie, São Paulo, v. 3, n. 1, p. 135-157, 2003.

REAd - Edição 68, Volume 17, No 1, jan/abr 2011 - p. 149-180 
BOTELHO, Eduardo. Administração Inteligente. 3. ed. São Paulo: Atlas, 1998.

BOYATZIS, R. E. The competent manager: A model for effective performance. New York: John Wiley \& Sons, 1982.

COOPERS M; LYBRAND D. Remuneração por habilidades e por competências. São Paulo, Atlas, 1997.

COUTINHO, L.; FERRAZ, J. C. Estudo da competitividade da indústria brasileira. 3.ed. Campinas: Papirus, 1994.

DEGEN, Ronald Jean; MELO, Álvaro Augusto Araújo. O empreendedor: fundamentos da iniciativa empresarial. 8. ed. São Paulo: Makron Books, 1989.

DURAND, T. Forms of incompetence. In: Fourth International Conference on competenceBased Management. Anais... Oslo: Norwegian School of Management, 1998.

DUTRA, J. S. Competências: conceitos e instrumentos para a gestão de pessoas na empresa moderna. São Paulo: Atlas, 2004.

Gestão por competências. São Paulo: Editora Gente, 2001.

FACHIN, O. Fundamentos da metodologia. São Paulo: Atlas, 1993.

FANDT, P. Management skills: Practice and experience. St. Paul, MN: West Publishing Co., 1994.

FERRAZ, J. C. et al. Made in Brazil: desafios competitivos para a indústria. Rio de Janeiro: Campus, 1999.

FLEURY, A.; FLEURY, M. T. L. Estratégias empresariais e formação de competências. 3. ed. São Paulo: Atlas, 2004. 
Estratégias empresariais e formulação de competências: um quebra-cabeça caleidoscópico da indústria brasileira. 2.ed. São Paulo: Atlas, 2001.

GERBER, Michael E. O mito empreendedor. São Paulo: Saraiva, 1996.

GIL, Antonio Carlos. Técnicas de pesquisa em Economia e elaboração de Monografias. São Paulo: Atlas, 2000.

. Pesquisa Social. São Paulo: Atlas, 1999.

Como elaborar projetos de pesquisa. 4. ed. São Paulo: Atlas, 2002.

GRAMIGNA, M. R. Modelo de competências e gestão de talentos. São Paulo (SP): Makron Books; 2001.

GRIFFIN, J. Como conquistar e manter o cliente fiel. São Paulo, Futura, 1998.

HITT, M. A.; IRELAND, R. D.; HOSKISSON, R. E. Administração estratégica. São Paulo: Pioneira, 2002.

HIROTA, E. H.; FORMOSO, C. T. O processo de aprendizagem na transferência dos conceitos e princípios da produção enxuta para a produção. 2003, disponível em: <http://www.ea.ufrgs.br/gap/arquivo1/arquivo1>. Acesso em: 20 maio 2005.

KANTER, R. M. Thriving Locally in the Global Economy. Harvard Business Review. p. 151-158, set/oct, 1995.

KATZ, R. L. As habilitações de um administrador eficiente. São Paulo: Abril, 1986.

KUPFER, D. Padrão de concorrência e competitividade. Rio de Janeiro: IEI/UFRJ, 1991.

LEVY, M.; WEITZ, B. Administração de varejo. São Paulo: Atlas, 2000.

REAd - Edição 68, Volume 17, No 1, jan/abr 2011 - p. 149-180 
LE BOTERF, G. Desenvolvendo a competência dos profissionais. 3. ed. Porto Alegre: Artmed, 2003.

De la compétence. Paris: Le Editions d'Organisation, 1994.

MARCONI, M. A.; LAKATOS, E. M. Fundamentos de metodologia científica. 5. ed. São Paulo: Atlas, 2003. 311 p.

MELLO, Sérgio Carvalho Benício de ; FONSÊCA, Francisco Ricardo Bezerra ; PAIVA JÚNIOR, Fernando Gomes de . Competências Empreendedoras do Dirigente de Empresa de Base Tecnológica: Um Caso Empresarial de Sucesso. Revista de Administração Mackenzie, v. 8, p. 50-76, 2007.

MIRANDA, S. V. Identificando competências informacionais. Disponível em www.scielo.br/scielo.php?pid=S0100-19652004000200012\&script=sci_arttext. Acesso em 28 jun. 2006.

MUSSAK, Eugênio. O entusiasmo do empreendedor. Vencer, São Paulo, n. 56, p.98, abr., 2004.

PARRY, Scott. B. The quest for competencies. Training, P.48-54, Jul 96.

PELISSARI, Anderson Soncini; GONZALEZ, Inayara Valéria Defreitas Pedroso; VANALLE, Rosângela Maria. Gestores de Pequenas Empresas: Estudo do Papel e das Funções Gerenciais. In: SEGeT. IV Simpósio de Excelência em Gestão e Tecnologia, 2007, Resende/RJ. v. 1. p. 1-16.

PELISSARI, A. S. Processo de formulação de estratégias em pequenas empresas com base na cultura corporativa e competências gerenciais. 2007. $221 \mathrm{f}$. Tese (Doutorado em Engenharia de Produção) - UNIMEP, Programa de Pós-Graduação em Engenharia de Produção da Faculdade de Engenharia, Arquitetura e Urbanismo, Santa Bárbara d'Oeste, 2007.

O Perfil de Qualificação Profissional dos Empresários das Pequenas Empresas do Ramo de Confecções da Glória, Vila Velha - ES. 2002. Dissertação (Mestrado em Engenharia de Produção) - Programa de Pós-graduação em Engenharia de Produção, Universidade Federal de Santa Catarina, Florianópolis, 2002. 
PEREIRA, Heitor José; SANTOS, Sílvio Aparecido dos. Criando seu próprio negócio: como desenvolver o potencial empreendedor. Brasília: Ed. SEBRAE, 1995.

PIMENTA, S. M. ; BRASIL, E. R. . Gestores e competências organizacionais no Terceiro Setor em Itabira-MG. Gestão e Regionalidade, v. 22, p. 78-89, 2006.

PINHEIRO, M. Gestão e desempenho das empresas de pequeno porte. 1996 Tese (Doutorado) - Faculdade de Economia, Administracao e Contabilidade, Universidade de Sao Paulo, Sao Paulo, 1996.

PINSONNEAULT, A.; KRAEMER, K. L. Survey research in management information systems: an assessement. Journal of Management Information System, 1993.

PORTER, M. E. Competição: estratégias competitivas essenciais. 3. ed. Rio de Janeiro: Campus, 1998.

PRAHALAD, C. K. Em busca do novo. HSM Management, São Paulo, n. 7, p. 6-12, mar/abr. 2001.

RESENDE, Enio. O livro das competências: desenvolvimento das competências: a melhor auto-ajuda para pessoas, organizações e sociedade. Rio de Janeiro: Qualitymark, 2000.

RICHARDSON, R. J. Pesquisa Social: métodos e técnicas. São Paulo: Atlas, 1999.

ROBBINS, Stephen. Administração: mudanças e perspectivas. São Paulo: Saraiva, 2002.

ROPÉ, F.; TANGUY, L. (org.). Saberes e competências. Campinas: Papirus, 2001.

RUAS, R. . Literatura, dramatização e Formação Gerencial: a apropriação de práticas teatrais ao desenvolvimento de competências gerenciais. Organizações \& Sociedade, Salvador, v. 12, p. 121-142, 2005.

A problemática do desenvolvimento de competências e a contribuição da aprendizagem organizacional. In: Gestão estratégica do conhecimento: integrando aprendizagem, conhecimento e competências. São Paulo: Atlas, 2000.

SEBRAE-ES. Vestuário. Disponível em: www.sebraees.com.br. Acesso em 15 dez. 2006.

REAd - Edição 68, Volume 17, No 1, jan/abr 2011 - p. 149-180 
SEBRAE/SP. Serviço Brasileiro de Apoio às Micro e Pequenas Empresas. Gestão empresarial: apoio à formulação de micro e pequenas empresa. Fascículo 3, p.103-10, 1999.

SEBRAE. Estudos da Pequena Empresa. Disponível em www.sebrae.com.br. Acesso em 20 fev. 2007. nov. 2005.

Estudos da Pequena Empresa. Disponível em www.sebrae.com.br. Acesso em 11

SILVA, A. L. Tecnologia da informação no varejo o caso do Pão de Açúcar Delivery In: MARCOVITCH, J. Tecnologia da informação e estratégia empresarial. São Paulo: Futura, 1997.

SCHOEMAKER, Michiel; JONKER, Jan. Managing intangible assets: An essay on organising contemporary organisations based upon identity, competencies and networks. Journal of Management Development. v. 24, n. 6, 2005.

SOUZA, M. C. A. F. Pequenas e médias empresas na reestruturação industrial. Brasilia: Sebrae, 1995.

STONER, James Arthur Finch; FREEMAN, R. Edward. Administraçãa. 8 ed. Rio de Janeiro: Prentice Hall, 1999.

SWIERINGA, J.; WIERDSMA, A. La Organización que Aprende. Buenos Aires: 1992.

SVEIBY, K. E. A nova riqueza das organizações. Rio de Janeiro: Campus, 1998.

TERENCE, A. C. F. Planejamento estratégico como ferramenta de competitividade na pequena empresa. 2002. Dissertação (Mestrado em Engenharia de Produção) - Programa de Pós-graduação em Engenharia de Produção, Universidade de São Paulo, São Paulo, 2002.

TRIVIÑOS, A. N. S. Introdução à pesquisa em ciências sociais: a pesquisa qualitativa em educação São Paulo: Atlas, 1995.

VALLE, P. R. A; MACKE, J. Metodologia para identificacao de competencias em uma empresa de pequeno porte. In: XXVIII ENANPAD, 2004. Anais... Campinas, 2005. (CDROM).

REAd - Edição 68, Volume 17, No 1, jan/abr 2011 - p. 149-180 
ZARIFIAN, P. Objectif compétence. Paris: Liaisons, 1999.

\title{
RESUMO
}

O atual cenário globalizado colocou as pequenas empresas brasileiras sob pressão de novas forças competitivas. $\mathrm{O}$ grande desafio dos gestores das pequenas empresas é o de buscar a sensibilidade no mercado para sua empresa, a inovação e a tecnologia do produto e sua adequação a novos modelos de gestão. O presente artigo resulta de uma pesquisa que aborda os diversos aspectos das competências gerenciais em pequenas empresas, e o objetivo geral é analisar as competências gerenciais consideradas essenciais na visão dos gestores das pequenas empresas de confecções do município de Vila Velha/ES. A análise foi conduzida através de pesquisa exploratório-descritiva e utilizou-se como delineamento o levantamento (survey). Foi aplicado um questionário com perguntas abertas e fechadas a 48 gestores das Pequenas Empresas do Município de Vila Velha/ES. Os gestores entrevistados revelaram dar maior ênfase as competências técnica e conceitual, visto que valorizam o conhecimento do negócio e seu ambiente, além da identificação tanto das vantagens competitivas como das oportunidades, ambos relevantes na condução de suas empresas.

Palavras-chave: Pequena empresa; Competitividade; Competências gerenciais; Desenvolvimento de Competências Gerenciais; Competências gerenciais em pequenas empresas.

\section{MANAGEMENTAL COMPETENCE: A STUDY IN SMALL COMPANIES OF CONFECTIONS}

\begin{abstract}
The actual global scenery places the Brazilian small business under the pressure of new competitive forces. The big challenge for their managers is to determine the market's sensibility, the innovation and the technology of the product, as well as their adaptation to new management models. This paper results from a research that approaches the various aspects of managerial competence in small businesses, and the objective general is analyze managerial competencies considered essential in view of managers of small clothing companies in the city of Vila Velha/ES. The analysis was conducted through exploratorydescriptive research and the design used was the survey. A questionnaire was applied to open and closed questions to 48 entrepreneurs of Small Companies in the City of Vila Velha/ES. The managers interviewed revealed greater emphasis to technical and conceptual skills, because they value the knowledge of the business and its environment, beyond the identification of both the competitive advantage of opportunities, both relevant in the conduct of their businesses.
\end{abstract}

Keywords: Small company; Competitiveness; Managerial competence; Development of managerial competence; Managerial competence in small companies. 